【関東支部研究会記録】

[2008年10月18日：東京大学農学部]

テーマ：穀物高騰と我が国のフードシステム

\section{座長解題「世界の食料需給一長期的視点から見た 近年の動向一」}

\section{和光大学 小林 弘明}

\section{シンポジウムのテーマである「穀物価格高騰と} 我が国のフードシステム」を論ずる際の前提条件、 (1)近年の価格高騰、(2)2008年秋時点の状況、(3)中 長期的視点からみた国際穀物市場の動向、(4)わが 国にとっての意味合い、についての評価を座長解 題としてとりまとめる。

(1)近年の穀物価格高騰の要因として米国などの バイオ燃料生産の拡大が指摘された。しかし冷静 な判断としては、天候不順などによる供給変動と 在庫率の低下が基本的な要因であり、これにバイ オ燃料需要、投機需要および一部の国による政策 変化が加わった複合的要因によるものと考えられ る。

(2)主要穀物の国際価格は落ち着きを取り戻しつ つあるものの、2000年代初め頃に比べればかなり の高い水準にある。FAOなどによると、この状 況はしばらく継続するが、一方で穀物生産は史上 最高と見込まれており、当面のトレンドは価格下 落であろう。

(3)長期的には、本年前半の穀物価格水準は、実 質価格（米ドル）で評価すると驚くほどの高水準 ではない。秋時点の水準は、96年頃とそれほど違 わない。80年代以降、穀物市場が過㮃基調にある という基本的な状況が大きく変化したとは判断し づらい。米国・EUのバイオ燃料生産の推進は、 輸出補助的な政策で処理していた過㮃農産物を、 やはり大規模な財政的支援によって「処理」して いるともみなせる。経済発展を達成しつつある 国々が、次々と農業保護的な政策に傾斜している。

(4)わが国にとっての意味合いでは、かりに現状 をある程度上回る国際価格水準であっても、国内 市場への影響は限定的であろう。飼料価格の高騰 は、畜産業にダメージを与えるが、内外価格差は
なお大きく、これを国内産に切り替えていくべき かどうかは別の話であろう。

\section{米国のエタノール政策と穀物メジャーの戦略}

\section{國學院大學 茅野 信行}

2008年10月18日に開かれた関東支部会で、「米 国のエタノール政策と穀物メジャーの戦略」とい うテーマで報告を行った。

先ず、穀物メジャーとは、世界の穀物輸出の担 い手であり、圧倒的な生産力をもつ米国の産地か ら、食糧を求める世界中の国々へ合理的な価格で 大量にしかも迅速に送り届ける能力を競い合って いる流通業者である。またその非イデオロギー性 と無国籍性が特徴である。

次いで、穀物メジャーの消長について、対ソ穀 物大量輸出直後の1973年と、米国でエタノール政 策が導入されてから 2 年後の 2008 年の一覧表を示 したが、その入れ替わりが激しいことに驚かされ る。

さらに、穀物メジャーの機能と穀物事業の本質 について述べ、穀物メジャーの利益の源泉はライ ン (系列) ・エレベーターの手数料収入と、輸出 エレベーターのフォビング（積み替え）収入にあ ることを明らかにした。

一方、米国のエタノール政策には、環境問題へ の貢献、中東産輸入原油への依存度の低下、トウ モロコシ価格の低迷に苦しむ農家の救済、価格支 持計画にもとづく財政支出の削減という一石四鳥 の効果がある。しかし、トウモロコシ由来のエ夕 ノールの最大の弱点は石油ガソリンに対する価格 競争力がないことである。これに価格競争力を持 たせるには優遇税制を欠かすことはできない。

これに加えて、穀物メジャーはエ夕ノール事業 への進出について温度差があり、ADMは積極的、 カーギルは消極的、穀物・エネルギー農協のCHS は積極的と、事業戦略の違いが鮮明であることに 言及した。

忘れてならないのは、国際穀物市場における米 国の地位はレジデュアル・サプライヤー（供給の 最後の拠り所）であることである。この点に関し 
て米国は作付面積の拡大、GMO種子の導入、密 植の励行によってその地位を維持することができ ると考えられる。

最後に、エタノール政策によって米国のトウモ ロコシ輸出が減少すれば、不足する分をただちに ブラジル、アルゼンチン、ウクライナなどから調 達して供給する。これは穀物メジャーの経営が 「穀物に祖国なし、穀物メジャーに国籍なし」と いう前提の上に成り立っているからである。

07年末から08年 7 月初めにかけての未曾有の穀 物高騰の原因は、需給逼迫、ドル安、エタノール 政策によるトウモロコシの需要拡大、投機資金の 流入にあることにも言及した。この短い報告が穀 物メジャーに対する理解を深めていただく一助に なったとすれば嬉しい。

\section{飼料価格高騰と国内畜産の対応方向一飼料米の可 能性についてー}

\section{東京農業大学 信岡 誠治}

輸入穀物価格の上昇により飼料価格が高騰し、 わが国の畜産は危機に直面している。そこで、最 近国産の飼料穀物としての飼料米の生産と利用が 注目されている。飼料米はこれまで、内外価格差 が大きいことから非現実的とされてきたが、 $10 \mathrm{a}$ 当たり $1 \mathrm{t}$ レベルの収量が見込める超多収飼料米 品種が開発されてきたことから国内での飼料米の 実用化が射程距離に入ってきた。水田を全て水田 としてコメ生産に利用すれば、将来的な飼料米の 生産量は 90 万 ha $\times 1.25 \mathrm{t}=1,125$ 万 $\mathrm{t}$ となり日本が

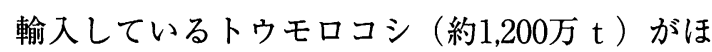
ぼ飼料米で代替できる。

政策的には現在、飼料米は主食用米の転作とい う位置づけであるが、将来的には本作として位置 づけていくべきである。本作となれば麦や大豆と 同じように生産増強の戦略重要品目として位置づ け、水田経営所得安定対策 (品目横断的経営安定 対策）の中に組み込んでいくことが必要となる。 当然、水田転作ということがなくなれば減反を廃 止し増反に政策の舵を切り替え、思い切った増産 と規模拡大路線への政策展開が求められる。
飼料米の利用面においては技術的には飼料米は 全ての畜種で給与可能である。その際、栄養面か らもモミ米を利用するのが効果的で、食用米への 横流れを防ぐ観点からも有効である。飼料米を給 与した畜産物は今年から各地で販売が開始されて いるが、新しい畜産物としてのマーケティング開 発が進められている。

最大の問題は飼料米のコストである。一挙にモ ミ米で $1 \mathrm{~kg}$ 当たり40〜50円に引き下げることは困 難なので、当面は水田農家の経営が成り立つ水準 を見極めた政策的な支援（直接支払い）が必要と なる。また、水田農家と畜産農家の連携とマッチ ングも大きな課題で関係機関・団体が果たす役割 も重要となる。

\section{穀物価格の高騰に対応した小麦・小麦粉関連産業 の対応}

食品産業新聞社 加藤 光司

年間 500 万 $\mathrm{t}$ の輸入小麦の政府売渡価格は、 07 年 4 月の「新たな麦制度」開始前に比べ、08年 10 月期には $59 \%$ も上げられた。新たな麦制度は、 国際小麦相場の変動に連動して国内の政府売渡価 格も変動（当面 4 月・10月の年 2 回）させる仕組 みで、06年秋から始まった小麦相場の高騰により、 主要 5 銘柄で 07 年 4 月期平均 $1.3 \% 、 07$ 年 10 月期 一律 $10 \% 、 08$ 年 4 月期一律 $30 \%$ 、08年 10 月期一律 $10 \%$ 引上げられた。輸入麦の国家貿易制度を採る 日本では、国内製粉メーカーは原則として国（農 水省）からしか、また国が決めた売渡価格でしか 購入することができない。このため、製粉メーカ 一は、小麦粉価格に転嫁するしかヘッジできない 仕組みとなっている。

製粉メーカーは 4 期とも連動して小麦粉価格の 值上げを実施。小麦粉を主な原料とする小麦粉二 次加工業（製パン、製麺、製菓メーカー等）も 3 回までは価格改定（容量変更による実質值上げを 含む）を行ったが、強大なバイイングパワーの存 在により、量販店等の店頭価格は、製パン・即席 麺では十分に上がっていない。4 回目となる08年 10 月期の $10 \%$ 引上げと、これに伴う小麦粉価格の 
值上げ（25kg当たり約 250 円、07年10月期も $10 \%$ 引上げだが小麦粉価格值上げ額は $25 \mathrm{~kg} 180$ 円前後） に対し、製パン・即席大手が、消費不況下で「こ れ以上店頭価格を上げることが困難」と報道され る。しかし、年間100万 $\mathrm{t}$ 近くの小麦粉を使用す る小麦粉二次加工大手にとっては、半年間で50億 円のコストアップとなる計算であり、何らかの対
策が不可避。結局、製品の量目削減や原料配合変 更（グレードダウン）が避けられない。これは消 費者には「隠れた值上げ」と映る。

国際穀物価格の大変動、麦制度の変更などにつ いて、製粉 - 小麦粉二次加工とも企業の社会的責 任の一環として「今、何を消費者に伝えていかな ければならないか」が問われる局面を迎えている。 